295 FETAL DEVELOPMENT IN THE DIABETIC MOUSE, A MODEL OF GENETIC MATERNAL DIABETES. H.C. Nielsen,
C. Gebhardt, J.B. Warshaw, Dept. of Pediatrics, Southwestern Med. School, DaTlas, Texas.

The heterozygous diabetes mouse $(\mathrm{db} /+)$ has been found to have glucose intolerance during pregnancy. To determine if weights, lung, liver and placenta protein, DNA and glycogen (G) content, and lung and liver phospholipids. Controls were from diabetes gene (misty). Fetuses were studied on day 18 of diabetes gene (misty). Fetuses were studied on day 18 of
gestation $(19=$ term). Fetuses of $(\mathrm{db} /+)$ pregnancies weighed gestation $(19=$ term $)$. Fetuses of $(\mathrm{db} /+)$ pregnancies weighed
more than controls $(1091 \pm 12 \mathrm{mg}$ vs. 1022 $20 \mathrm{mg}$; mean $\pm \mathrm{SE}$; $\mathrm{p}<.005)$ and placentas and lungs also weighed significantly more. Giycogen content was higher in liver $(1340 \pm 54 \mathrm{mg} \mathrm{G} / \mathrm{gram}$ prot vs $623 \pm 42 \mathrm{mg}$ G/gram prot; mean $\pm S E ; \quad p<.001$ ) and placenta $(228 \pm 16 \mathrm{mg} \mathrm{G} / \mathrm{gram}$ prot vs $106 \pm 8 \mathrm{mg} \mathrm{G} / \mathrm{gram}$ prot; $\mathrm{p}<.001)$ of differences were found in liver and placento protein on differ con $(\mathrm{db} /+)$ pregnancies had higher phosphatidylchotine content of lung and liver, with significantly less phosphatidylglycerol lung and liver, with significantly less phosphatidylglycerol
and more phosphatidylinositol in lung. These data show that fetal growth and development is abnormal in ( $\mathrm{db} /+)$ pregnancies consistent with abnormal fuel metabolism. This provides a usefut model for studying fetal growth and development during genetic maternal diabetes.

296 IN VITRO SYNTHESIS OF SURFACTANT ASSOCIATED

APOLIPOPROTEIN A: DEVELOPMENTAL ASPECTS. Lawrence Nogee, Carol Dion, D. Lorow, Jeffrey Whitsett. University of Cincinnati College of Medicine of Medicine, Ohio

Apolipoprotein A is a major surfactant associated protein localized to Type II cells in adult lung. We now demonstrate in vitro synthesis of apo $A$ in lung slices, adult Type II epithelial ceTls and fetal epithelial cells in organotypic culture. Synthesis and secretion of apo A was assessed in cells and media after S-methionine labelling; apo A was immunoprecipitated with antisera and identified by 2D-IEF-SDS-PAGE. Ful ly sialated apo A (Mr=26-36,000) was identified in media from adult rat lung slices and purified adult Type II cells. Apo A synthesis by adult Type II cells was optimal in freshly isolated cells: 1abelling was undetectable after $24 \mathrm{hrs}$. in culture. Intracellular forms of apo A were less acidic, $M r=30-34,000$, representing partially glycosylated peptides. Apo $A$ synthesis was undetectable in slices of fetal rat lung (day 18 of gestation). However, organotypic cultures of fetal epithelial cells isolated on day 19 of gestation, synthesized fully glycosylated forms of apo A after culture for 3-4 days. These studies demonstrate that apo $A$ synthesis and secretion is developmental ly regulated in Type II epithelial cells. Apo A synthesis is rapidly lost in primary culture of adult Type II cells but maintained in organotypic cultures of fetal cells. Major intracellular forms of apo A lack cultures of fetal cells. Major intracellular forms of apo A lack
complete glycosylation and only a small fraction of cellular apo A exists as the mature secreted form.
208 ALTERED PERINATAL GLUCAGON-PHOSPHOENOLPYRUVATE CARBOXYKINASE (PEPCK) RELATIONS IN THE GROWTH RETARDED RAT. Edward S. Ogata, Mary E. Bussey, Sandra Finley and Andrew LaBarbera, Northwestern Depts of Pediatrics, $\mathrm{OB} / \mathrm{Gyn}$ and Physiology, Chicago, IL. Since diminished gluconeogenic enzyme activity is a cause of hypoglycemia in the growth retarded neonate, we characterized the relation of glucagon, an inducer of gluconeogenic enzymes, to the appearance of hepatic PEPCK, a key gluconeogenic enzyme. Fetal and neonatal rat pups were rendered growth retarded by maternal bilateral uterine artery ligation (L) on day 18.5 (term 21.5). Pups of L, sham (S), and nonoperated (N) mothers had significantly different body and placental mass on days $19.5-21.5(\mathrm{~L}<\mathrm{S}<\mathrm{N})$. Glucose availability was limited in on day 19.5 since fetal glucose (L $37 \pm 5 ; \mathrm{S} 65 \pm 6$; $\mathrm{N} 72 \pm 5 \mathrm{mg} / \mathrm{dl}$; $\mathrm{p}<.0 \mathrm{I}$ ) and fetal/maternal glucose ratios differed ( $\bar{L} \overline{<} \mathrm{s}<\mathrm{N})$. Despite this, glucagon and PEPCK were not stimulated in $\mathrm{L}$ fetuses. Glucagon $(516-552 \mathrm{pg} / \mathrm{mI})$, insulin, and hepatic PEPCK (.078-.096 $\mu$ moles PEP/g liver/min) did not differ between L, S, and $\mathrm{N}$ fetuses. At birth, L pups had significantly greater glucagon surge than $\mathrm{S}$ and $\mathrm{N}$, but did not increase PEPCK as $\mathrm{S}$ and $\mathrm{N}$ did (120 min: L . $147+.019 ; \mathrm{S} .223+.031 ; \mathrm{N} .201+.019$ umoles PEP/ g liver/min; $\mathrm{p}<.01)$. Exogenous $\bar{g}$ lucagon induced PEPCK equivalently in $\mathrm{L}, \mathrm{S}$, and $\mathrm{N}$ (day 20.5) fetuses and newborns but not in day 19.5 fetuses. Little PEPCK induction occurs during late fetal life, and exogenous glucagon can induce PEPCK on day 20.5 and at bixth. L newborns, despite excessive glucagon surge, cannot induce PEPCK due to either limited secretory capability or relative insensitivity to glucagon.

\section{$\dagger 299$}

NEONATAL ADAPTATION: SYMPATHOADRENAL AND ENDORPHIN (END) RESPONSES TO DELIVERY IN TERM AND PRETERM LAMBS. J.F. Padbury, Y. Ogata, D.L. Wang, D.H. Polk, C.C. Callegari and R.W. Lam, UCLA School of Medicine,

A marked increase in plasma catecholamines (CAT) at birth has been described in animals and man. This study was conducted to determine whether the magnitude and duration of the CAT surge are similar in preterm ( 130 days, $n=4$ ) and term lambs (145 days, $\mathrm{n}=6$ ), and to correlate plasma CAT and plasma END levels in the acutely exteriorized fetal lamb. CAT were measured by radioenzymatic assay and END by specific radioimmunoassay. Preterm zymatic assay and END by specific radioimmunoassay. Preterm of natural sheep surfactant intratracheally prior to the first breath. Baseline CAT \& END were similar in the term and preterm lambs. Following umbilical cord cutting there was a marked increase in circulating norepinephrine (NE) and epinephrine (E) levels. Peak preterm NE $(2.2 \pm 0.6 \mathrm{ng} / \mathrm{ml}$ at $1 \mathrm{hr})$ was greater than peak term NE $(1.0 \pm 0.2 \mathrm{ng} / \mathrm{ml}$, at $5 \mathrm{~min})$. Peak preterm $\mathrm{E}$ also later and greater than peak term E $(2.9 \pm 0.9 \mathrm{ng} / \mathrm{ml}$ at $1 \mathrm{hr}$ vs $0.9 \pm 0.2 \mathrm{ng} / \mathrm{ml}$ at $15 \mathrm{~min}$, respectively $\mathrm{p}<.01$ ). Similarly, peak plasma END in preterm animals $(2.2 \pm 0.1 \mathrm{ng} / \mathrm{ml}$ at $3 \mathrm{hrs})$ was peak plasma END in preterm animals $(2.2 \pm 0.1 \mathrm{ng} / \mathrm{ml}$ at $3 \mathrm{hrs}$ ) was
later and greater than at term $(1.1 \pm 0.2 \mathrm{ng} / \mathrm{ml}$ at $15 \mathrm{~min})$. END was positively correlated with $N E$ and $E$ in both term and preterm was positively correlated with $N E$ and $E$ in both term and preter
animals $(p<.05)$. Conclusions: 1) Preterm animals have a delayed, exaggerated CAT surge following delivery, 2) The peak plasma END response parallels the peak of plasma CAT. Speculation: The CAT surge at birth is an important adaptive phenomenon and may be modulated by changes in the END system.
PROTEIN KINASE C (PK-C) IN THE DEVELOPING RAT LIVER 297 AND HEART. Akihiko Noguchi, John DeGuire, and Paul Pediatric Research Institute, Cardinal Glennon Memorial Hospital for Children, St. Louis, Mo.

Ca dependent, phospholipid regulated protein kinase (PK-C) serves a cructal role for receptor activation by substances such as $\alpha$-adrenergic agonists which stimulate phosphatidylinositol breakdown. Ontogeny of $\alpha_{1}$-receptors is known to be organ specific and distinct from $\beta$-receptors. To assess receptor-protein kinase relationship, ontogeny of $\mathrm{PK}-\mathrm{C}$ and cAMP dependent protein kinase (PK-A) activities were compared to cytosol from rat liver and

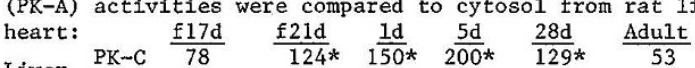
$\begin{array}{lllllccc}\text { Liver } & \text { PK-C } & 78 & 124 * & 150 * & 200 * & 129 * & 53 \\ & \text { PK-A } & 94 \S & 126 \S & 143 \S & 86 \S & 55 & 53\end{array}$ Heart PK-C 154* $176 * 124 * 198 \quad 111 \quad 63$

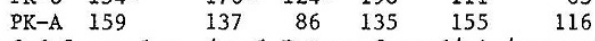
means of 6-8 samples ( $\mathrm{pmo1} P$ transferred/min $/ \mathrm{mg}$ protein) *, §: different from adult $\mathrm{P}<0.05$ to 0.00 Cytosol/particulate ratio of $\mathrm{PK}-\mathrm{C}$ at $21 \mathrm{~d}$ fetus were $0.72 \& 2.41$ for liver and heart and similar to adult. DEAE cellulose column separation of $\mathrm{PK}-\mathrm{C}$ showed a major and a minor peak, \& the minor peak was $\mathrm{Ca}$ and phosphatidylserine independent in liver and heart. This pattern did not change with age qualitatively. We conclude that $\mathrm{PK}-\mathrm{C}$ activity is higher perinatally, its subcellu lar distribution does not seem to change with age, and it is not correlated with PK $-A$ activity or previously reported $\alpha_{1}$-receptor density in these organs. We speculate that PK-C is not rate limiting in the receptor activation perinataliy.
LACK OF DRUG EFFECT ON OXYGEN INDUCED RETINAL ARTERY

300 CONSTRICTION IN THE KITTEN Dale L. PhelpS University of Rochester School of Mediclne, Strong Memorial Hospital, Departments of Pediatrics and Ophthalmology, chester, New York

The initial injury in the animal model of oxygen induced retinopathy is thought to be irreversible arteriolar constriction. Since vitamin $E$ is beneficial in this model, its effect on early arteriolar constriction, as well as the effect of prostaglandin inhibitors (as used in the beagle model) were'tested. 3 day old kittens were placed in $80 \%$ oxygen and their retinas perfused with india ink $48 \mathrm{hrs}$ later. Pretreatment from day 1 with free tocopherol (vitamin E) $200 \mathrm{mg} / \mathrm{kg} /$ day IM, aspirin 20 $\mathrm{mg} / \mathrm{kg} /$ day orally, or indomethacin $0.5 \mathrm{mg} / \mathrm{kg} /$ day orally was compared to no drug treatment in oxygen and room air controls. 5 kittens were randomly assigned to each group. Additionally, the effects of $8 \%$ carbon dioxide in combination with $21 \%$ oxygen (room air), $80 \%$ oxygen, or aspirin plus $80 \%$ oxygen was studied.

Al1 treatments except room air control and $8 \%$ carbon dioxide in room air 02 resulted in near total obilteration of patent retinal vessels, as demonstrated with the india ink perfusions. Kittens in $8 \%$ carbon dioxide with only $21 \%$ oxygen had moderate attenuation of the smallest vessels and partial closure of the arterioles. This unexpected fatlure of carbon dioxide to cause vasodilitation is unexplained.

Vitamin $E$ does not exert its beneficial effect on oxygen induced retinopathy in the kitten by maintaining vessel patencey during hyperoxia. 